\title{
MENGOPTIMALKAN KOMUNITAS MEREK: ANTESEDEN DAN KONSEKUENSI DARI IKATAN PELANGGAN
}

\section{Gede Nandya Oktora Panasea}

\author{
Universitas Udayana, Bali, Indonesia \\ email : nandyaoktora@unud.ac.id
}

\begin{abstract}
ABSTRAK
Penelitian ini secara empiris mengkaji faktor-faktor kritis dalam pengelolaan komunitas merek dengan menggunakan pendekatan kualitatif. Pendekatan tersebut relevan dengan tujuan penelitian yakni untuk menganalisis cara mengoptimalkan komunitas merek dengan menelaah secara mendalam Critical Success Factors (CSF) komunitas merek Harley-Davidson di Indonesia. Responden yang diambil merupakan tokoh-tokoh kunci di komunitas merek HarleyDavidson yang memiliki kontribusi di komunitas. Pengambilan data dilakukan melalui wawancara (in depth interview) dengan pertanyaan semi terstruktur untuk mendapatkan data mengenai Critical Success Factors (CSF) dari komunitas merek Harley-Davidson di Indonesia. Konsistensi data diuji dengan menggunakan metode triangulasi sumber untuk menganalisis validitas dan sekaligus memperkaya data. Berdasarkan hasil penelitian ini ditemukan bahwa bahwa kelima Critical Success Factors (CSF) yang diteliti mendukung kesuksesan implementasi strategi komunitas merek Harley Davidson di Indonesia. Adapun kelima Critical Success Factors (CSF) tersebut yaitu ikatan dengan merek, faktor sosial, faktor fungsional, faktor hiburan, dan faktor ekonomi. Menariknya terdapat dua faktor pendukung yang mempengaruhi efektivitas dari strategi komunitas merek yakni produk dan pelanggan.

Kata Kunci : Critical Success Factors (CSF), komunitas merek, loyalitas
\end{abstract}

\begin{abstract}
This research empirically explain about critical factors in managing brand communities by using qualitative approach. The research analyzes the Critical Success Factors (CSF) of the Harley-Davidson brand community in Indonesia. The respondents taken are key figures in the Harley-Davidson brand community who have contributed to the community. Data is collected through in-depth interviews with semi-structured questions in order to finding the Critical Success Factors (CSF) from the Harley-Davidson brand community in Indonesia. This research finding there are five Critical Success Factors (CSF) that supported the successful implementation of the Harley Davidson brand community strategy in Indonesia. The five Critical Success Factors (CSF) are bonds with brands, social factors, functional factors, entertainment factors, and economic factors. Interestingly, there are two supporting factors that influence the effectiveness of brand community strategies namely products and customers.

Keywords: critical success factors (CSF), brand community, loyalty.
\end{abstract}




\section{PENDAHULUAN}

Keberadaan merek merupakan hal yang sangat penting karena merek merupakan representasi nilai yang ditawarkan sebuah produk kepada pelanggan. Janita (2009) menyatakan bahwa merek adalah kontrak kepercayaan antara perusahaan dan pelanggan karena merek menjamin adanya konsistensi bahwa sebuah produk akan selalu dapat menyampaikan nilai yang diharapkan pelanggan darinya. Menariknya, selain sebagai identitas sebuah produk, merek memungkinkan pemasar untuk mengembangkan hubungan dekat dengan pelanggan. Fournier (1998) menunjukkan bahwa pelanggan sering membentuk ikatan emosional dengan merek favorit mereka. Hal tersebut menunjukkan pentingnya membangun ikatan emosional antara merek dengan pelanggan mereka

Salah satu cara yang dilakukan untuk membangun ikatan emosional tersebut adalah dengan membentuk suatu komunitas merek. Hal tersebut sejalan dengan berbagai riset empiris mengenai komunitas merek (Carlson et al., 2008; Woisetschlager et al., 2008). Muniz dan O'Guinn (2001) menyatakan bahwa komunitas merek adalah salah satu instrumen untuk menguatkan hubungan antara pelanggan dan merek yang digunakan, komunitas merek didefinisikan sebagai komunitas yang terikat secara geografi dan mempunyai struktur sosial yang mengatur hubungan di antara pencinta merek. Stokburger-Sauer (2010) menambahkan bahwa komunitas merek sebagai kelompok sosial mampu menarik perhatian pelanggan-pelanggan individu yang kemudian membantu perusahaan untuk menjalin hubungan jangka panjang yang saling menguntungkan dengan pelanggannya.

Komunitas merek kini tidak hanya menjadi sekadar alat pemasaran bagi produsen, namun juga menjadi strategi bisnis jangka panjang untuk mempertahankan eksistensi sebuah merek (Fournier 2009). Keberhasilan komunitas merek ditunjukkan melalui indikator loyalitas pelanggan dan juga kesediaan pelanggan menjadi brand advocate bagi merek yang diusung oleh komunitas tersebut. Salah satu merek yang dinilai berhasil dalam membangun komunitas merek dengan baik adalah Harley-Davidson. Harley-Davidson memiliki komunitas merek yang dikenal dengan nama HOG (Harley Owners Group) yang diinisiasi oleh perusahaan dan juga komunitas-komunitas Harley-Davidson lainnya yang diinisiasi secara independen oleh pelanggan Harley-Davidson yang tersebar di berbagai wilayah yang juga didukung penuh oleh perusahaan. Bronson dan Beaver (2004) menambahkan bahwa Harley-Davidson menawarkan gaya hidup yang unik dan memiliki karakter yang kuat di benak para pelanggan HarleyDavidson. Hal tersebut menunjukkan kesuksesan Harley-Davidson dalam membangun dan mengembangkan komunitas mereknya yang berujung pada terciptanya advocate customer dan ekuitas merek yang kuat.

Membangun sebuah komunitas merek yang efektif tidaklah mudah. Banyak perusahaan yang mampu membentuk sebuah komunitas bagi pelanggannya namun gagal untuk mengefektifkan komunitas tersebut menjadi instrumen bagi perusahaan untuk lebih dekat dan meningkatkan loyalitas pelanggan terhadap merek yang diusung. Menurut Coulson-Thomas (2004) dalam membangun strategi bisnis yang 
baik, diperlukan identifikasi faktor-faktor penentu keberhasilan terhadap strategi tersebut yang sering disebut dengan Critical Success Factors (CSF). Konsep CSF pertama kali diperkenalkan Daniel (1961) yang kemudian dipopulerkan oleh Rockart (1979) yang didefinisikan sebagai beberapa area dalam bisnis yang apabila terpenuhi dengan baik maka akan menyebabkan keberhasilan dan kinerja yang kompetitif bagi organisasi. Leidecker dan Bruno (1984) menambahkan bahwa CSF adalah karakteristik, kondisi, dan variabel yang bilamana dikelola dan dipelihara dengan baik maka akan memiliki dampak yang signifikan terhadap keberhasilan dari suatu organisasi. Secara ringkas CSF dapat didefinisikan sebagai faktor-faktor yang sangat penting yang menentukan keberhasilan atau kegagalan suatu usaha.

Berdasarkan latar belakang tersebut, penelitian ini menganalisis CSF dari komunitas Harley-Davidson yang telah terbukti mampu membangun komunitas yang efektif dalam meningkatkan loyalitas pelanggannya. Sesuai dengan pemaparan tersebut, penelitian ini mengacu pada temuan yang dilakukan pada penelitian sebelumnya yang dilakukan oleh Gummerus et al. (2012) dan Wirtz et al. (2013) mengenai faktor-faktor penting yang perlu difokuskan dari sebuah komunitas merek. Kedua penelitian tersebut mengemukakan bahwa keterlibatan pelanggan merupakan indikator yang penting dalam mengukur kesuksesan pengembangan komunitas merek. Ikatan pelanggan yang tinggi dalam suatu komunitas merek akan berimplikasi positif terhadap kepuasan dan loyalitas pelanggan dalam jangka panjang. Gummerus et al. (2012) mengemukakan bahwa terdapat 3 (tiga) faktor penting yang memotivasi ikatan pelanggan terhadap komunitas merek, antara lain; faktor sosial, faktor hiburan dan faktor ekonomi. Faktor sosial menjadi faktor paling penting yang berpengaruh pada motivasi intrinsik pelanggan terhadap komunitas merek. Secara umum anggota komunitas mendapat manfaat utilitarian dan kebanggan dengan menjadi anggota komunitas merek (Mcalexander et al., 2002); (Schau et al., 2009). Penelitian lain yang dilakukan oleh Wirtz et al. (2013) menambahkan bahwa terdapat faktor-faktor lain selain faktor sosial yang berpengaruh signifikan pada ikatan pelanggan di komunitas merek, yakni faktor ikatan terhadap merek, dan faktor fungsional. Namun pengaruh kelima faktor tersebut masih dimoderasi oleh beberapa faktor lainnya yaitu faktor produk, faktor situasional komunitas merek dan faktor pelanggan.

Penelitian ini menganalisis CSF pada penelitian sebelumnya secara mendalam dengan mengungkap implementasi dan peran masing-masing faktor dalam mendukung kesuksesan komunitas merek Harley-Davidson. HarleyDavidson terbukti mampu membangun dan mengembangkan komunitas mereknya hingga mampu berkontribusi terhadap terbentuknya advocate customer serta tumbuhnya sub-budaya baru di antara pelanggan yang berkontribusi tinggi terhadap penjualan dari produk-produk Harley-Davidson. Studi ini menganalisis motivasi pelanggan untuk membeli produk Harley-Davidson dan menjadi anggota komunitas Harley-Davidson, karena motivasi memegang peranan yang penting dalam proses pengambilan keputusan. Terkait dengan hal itu, penelitian ini menganalisis CSF yang terdiri dari faktor ikatan dengan merek, sosial, fungsional, hiburan dan ekonomi dari komunitas merek Harley-Davidson di Indonesia. 


\section{METODE PENELITIAN}

Metode yang digunakan dalam penelitian adalah metode penelitian deskriptif dengan pendekatan kualitatif. Sugiyono (2005) mengungkapkan bahwa penelitian kualitatif adalah penelitian yang digunakan untuk meneliti pada kondisi objek alamiah dimana peneliti merupakan instrumen kunci sehingga isi dari riset bersifat deskriptif dan cenderung menggunakan analisis. Sekaran and Bougie (2013:97), metode deskriptif sering digunakan untuk mengumpulkan data yang menggambarkan karakteristik dari seseorang, fenomena atau situasi. Hal tersebut juga sejalan dengan penelitian Stainback and Stainback (1984) yang menyatakan bahwa penelitian kualitatif yang bertujuan untuk melakukan investigasi data secara mendalam secara menganalisi korelasi antar data. Fokus penelititan ini ada pada permasalahan yang menyangkut fenomena-fenomena subjektif. Hal ini sesuai dengan tujuan penelitian yakni untuk mengungkap secara detail dan mendalam mengenai CSF dalam pengelolaan komunitas merek Harley-Davidson hingga mencapai kesuksesannya seperti sekarang. Sekaran dan Bougie (2013:336) memaparkan bahwa penelitian kualitatif merupakan data di dalam kata-kata, yang dapat berupa; transkrip wawancara, transkrip focus group, rekaman video, gambar, foto, artikel dan lain sebagainya. Alsharari and Al-Shboul (2019); (Campbel and Gregor (2004) menyebutkan bahwa ada langkah dinamik dan sistematik untuk meperlakukan temuan kualitatif agar layak digunakan sebagai data. Metode intepretatif dilakukan untuk menemukan bukti-bukti, keterkaitan data, analisa sehingga data dapat dintepretasikan. Dalam pendekatan induktif, topik utama, dan pola antar data akan muncul secara progresif dari sehingga apa yang adatelah dipelajari dapat dikomunikasikan kepada orang lain (Hatch 2002:148).

Menurut Milles and Hubberman (1992:16), kegiatan analisis pada penelitian kualitatif terdiri atas tiga alur kegiatan yang dilakukan secara simultan, yaitu reduksi data, penyajian data, dan penarikan kesimpulan. Reduksi data, penyajian data, dan penarikan kesimpulan merupakan proses siklus dan interaksi yang saling terkait pada saat sebelum, selama, dan sesudah pengumpulan data dalam bentuk sejajar yang membangun wawasan umum yang disebut analisis. Validitas data diuji dengan metode triangulasi. Triangulasi merupakan teknik yang digunakan untuk menguji konsistensi dan validitas data. Moloeng (2012:330) memaparkan triangulasi merupakan teknik pemeriksaan keabsahan data yang memanfaatkan sesuatu yang lain dalam membandingkan hasil wawancara pada objek penelitian. Nasution (2003:115)menambahkan bahwa triangulasi dapat dilakukan dengan menggunakan teknik yang berbeda yaitu melalui metode wawancara, observasi dan dokumen. Selain digunakan untuk mengecek kebenaran data, triangulasi juga dilakukan untuk memperkaya data dan menyelidiki validitas tafsiran peneliti pada data.

Sejalan dengan tujuan penelitian, teknik pengumpulan data pada penelitian ini menggunakan teknik wawancara mendalam secara semi-terstruktur dan focus gorup discussion. Teknik wawancara mendalam dilakukan untuk menggali informasi secara detail kepada responden dengan menggunakan instrumen wawancara semi terstruktur sehingga peneliti mendapatkan data sesuai kebutuhan penelitian (Stainback dan Stainback, 1984). Validitas data yang didapatkan dijuji dengan menggunakan metode triangulasi sumber. Prosedur triangulasi menjamin 
peneliti telah melakukan pembobotan dan validasi terhadap data yang didapat sehingga data dapat diandalkan (Scapens 2004:268)

Teknik pengambilan narasumber yang digunakan dalam penelitian dilakukan secara subjektif sesuai dengan kriteria yang diperlukan dalam penelitian. Dalam hal ini, kriteria yang digunakan dalam menentukan karakteristik responden adalah sebagai berikut; Narasumber adalah pria atau wanita, pelanggan kendaraan HarleyDavidson, dengan tingkat pendidikan minimal SMA/setara dan telah menjadi anggota komunitas Harley-Davidson minimal selama 5 tahun dan pernah menjadi pengurus organisasi di komunitas masing-masing. Dengan menggunakan kriteriakriteria tersebut, diharapkan mampu mendapatkan narasumber yang kredibel, yakni tokoh kunci di komunitas Harley-Davidson yang memiliki kompetensi dan pengalaman yang cukup di komunitas Harley-Davidson. Narasumber tersebut diharapkan mampu memberikan gambaran yang kuat serta data-data faktual mengenai komunitas merek Harley-Davidson di Indonesia.

Berdasarkan kriteria tersebut terpilih 9 orang responden yang merupakan orang-orang yang memiliki kompetensi dan informasi yang akurat mengenai komunitas Harley-Davidson di Indonesia. Para responden merupakan para pendiri dan pengurus aktif komunitas Harley Owners Group (HOG) dan Harley-Davidson Club Indonesia (HDCI) di Jakarta dan Bali. Kedua komunitas tersebut dipilih karena Harley Owners Group (HOG) sendiri merupakan komunitas resmi yang didirikan oleh perwakilan dealer Harley Davidson di Indonesia yang merupakan marketing tools dari principal Harley-Davidson Motor Company. Di sisi lain, Harley-Davidson Club Indonesia (HDCI) merupakan salah satu komunitas HarleyDavidson tertua dan terbesar di Indonesia. Kota Jakarta dan Denpasar dipilih sebagai lokasi penelitian karena merupakan lokasi basis penjualan HarleyDavidson terbesar di Indonesia. Adapun responden terpilih dilampirkan dalam tabel 1 berikut.

\section{Tabel 1.}

Daftar Responden

\begin{tabular}{lll}
\hline No. & \multicolumn{1}{c}{ Nama Responden } & \multicolumn{1}{c}{ Pengalaman di Komunitas Merek } \\
\hline 1. & A.A. Wiralaga & $\begin{array}{l}\text { Salah satu pendiri HDCI dengan pengalaman lebih dari 30 } \\
\text { tahun di komunitas merek Harley-Davidson. }\end{array}$ \\
2. & $\begin{array}{l}\text { Drs. H. Indrodjojo/ Indro } \\
\text { "Warkop" }\end{array}$ & $\begin{array}{l}\text { Salah satu pendiri HDCI, dengan pengalaman lebih dari } 40 \\
\text { tahun di komunitas merek Harley-Davidson. } \\
\text { Mantan karyawan Harley-Davidson di Milwaukee dan } \\
\text { anggota HDCI Bali dan HOG International. }\end{array}$ \\
3. & Willy Agustianto & $\begin{array}{l}\text { Mantan ketua HOG dengan pengalaman lebih dari 10 tahun } \\
\text { di komunitas Harley-Davidson. } \\
\text { Mantan pengurus HOG Bali masa bakti 2013-2016 dengan 5 } \\
\text { orang perwakilan dengan memiliki pengalaman lebih dari 10 } \\
\text { tahun. }\end{array}$ \\
\hline 5. & Sahat Manalu &
\end{tabular}

Sumber : data primer (diolah)

Penelitian Gummerus et al. (2012) dan Wirtz et al. (2013) menjelaskan bahwa terdapat beberapa aspek yang kritis yang mempengaruhi ikatanpelanggan pada komunitas merek, Dalam penelitian tersebut dipaparkan bahwa terdapat 5 (lima) CSF yang dimoderasi oleh 3 (tiga) aspek yang perlu diimplementasikan untuk 
meningkatkan ikatan pelanggan pada komunitas merek. Berikut Gambar 2.2. yang mengilustrasikan kerangka berpikir implementasi CSF dalam strategi pengembangan komunitas merek.

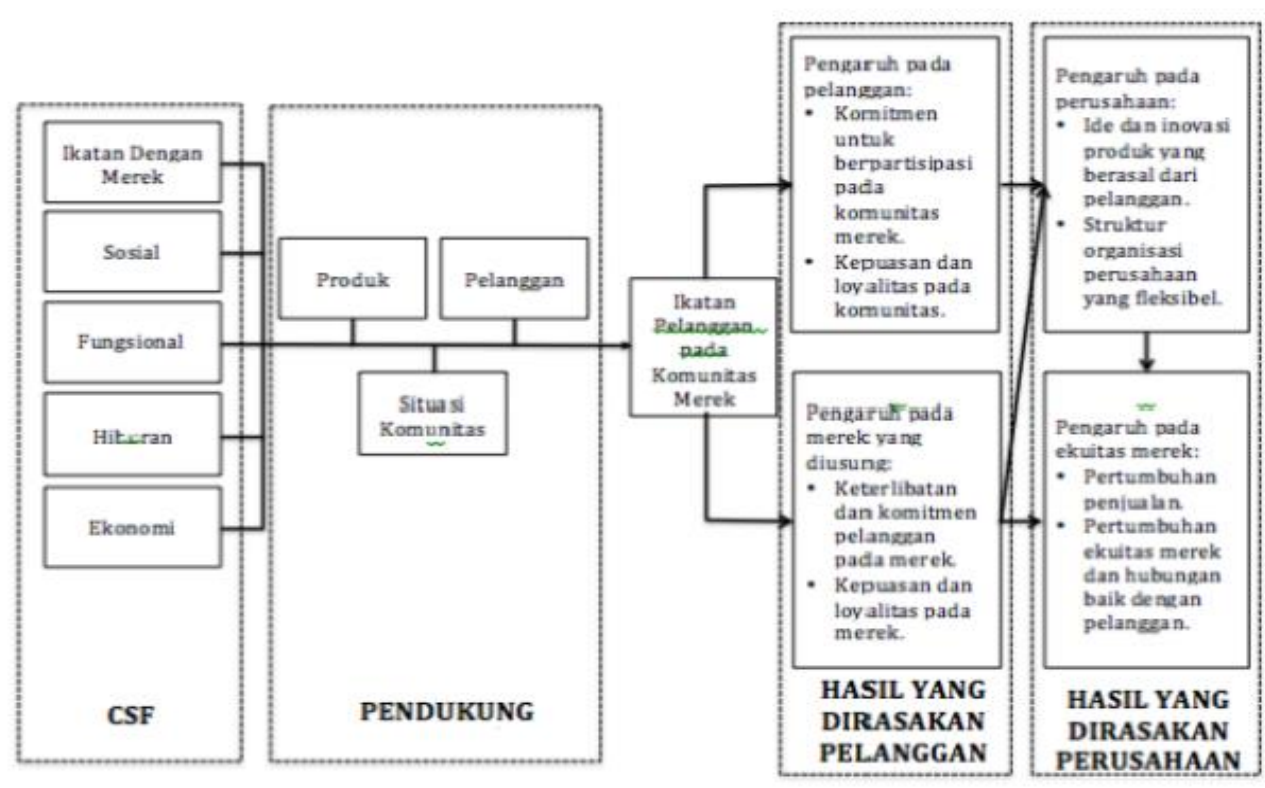

Gambar 1. Kerangka Penelitian

sumber: Gummerus et al. (2012) dan Wirtz et al. (2013)

\section{HASIL DAN PEMBAHASAN}

Wirtz et al. (2013) menyebutkan bahwa terjadinya proses identifikasi merek merupakan konstruk sosial yang melibatkan integrasi dari identitas yang melekat pada merek menjadi sebuah identitas diri. Menurut model identitas merek yang dikembangkan oleh Aaker (1996) bahwa terdapat dua kategori pada fungsi merek sebagai sebuah simbol, yakni fungsi simbolis yang didapat dari citra visual merek dan juga fungsi simbolis yang berasal dari sejarah merek. Salah satu motivasi pelanggan mengikuti sebuah komunitas merek dengan harapan bahwa komunitas merek mampu menjadi simbol bagi kehidupan mereka.

Eksistensi Harley-Davidson selama 117 tahun menjadikan merek tersebut memiliki ekuitas merek yang sangat kuat. Hal tersebut menjadikan citra merek Harley-Davidson dipersepsikan sebagai simbol dari kegagahan, kesuksesan, kebebasan serta prestise bagi para pnggunanya. Kekuatan citra merek HarleyDavidson membuat banyak pelanggan yang ingin mengintegrasikan identitas diri mereka dengan citra yang dimiliki oleh merek Harley-Davidson. Hal tersebut tentunya berimplikasi positif terhadap motivasi pembelian dari produk-produk Harley-Davidson. Untuk mengetahui apakah komunitas Harley-Davidson menjadi identitas diri dan simbol gaya hidup dari pelanggannya, berikut penuturan dari nasarumber.

"Namun tidak memungkiri bahwa Harley-Davidson memberikan image motornya orang-orang kaya. Karena memang harga Harley sendiri tidak terbilang 
murah dan juga butuh waktu senggang yang banyak buat mengendarainya. Tentunya hanya orang yang sudah mapan secara ekonomi yang mampu membelinya, sehingga jika kita lihat rentang umurnya didominasi oleh umur 35-45 tahun dimana orang sudah matang baik secara ekonomi maupun emosi. Jadi kalau Nandya lihat ada anak muda pakai Harley itu sudah bisa hampir dipastikan bahwa motor tersebut dibelikan orang tua nya." (BC)

"Jawabannya bisa ya bisa tidak ya. Memang benar ada beberapa teman-teman yang membeli motor itu karena senang dengan status. Tapi banyak juga temanteman yang membeli motor karena memang hobi menaiki motor tersebut, seperti saya. Kalau saya motornya pasti saya naikkin dan saya riding ke seluruh Indonesia maupun luar negeri." (SM)

BC dan SM sepakat bahwa tidak dapat dipungkiri jika Harley-Davidson baik itu produk maupun komunitasnya dipersepsikan sebagai motor untuk kalangan atas, sehingga tentunya memberikan prestise bagi pelanggannya, walaupun para pelanggan Harley-Davidson tidak semata-mata hanya mengejar prestise melainkan karena adanya kesamaan hobi yaitu mengendarai sepeda motor Harley-Davidson.

Berdasarkan hasil wawancara dengan para narasumber dapat diketahui bahwa Harley-Davidson baik dalam kapasitas sebagai merek maupun produk memiliki sinergi yang baik untuk mampu mewujudkan identitas diri dan status sosial pelanggannnya. Hal tersebut juga didukung oleh komunitas Harley-Davidson yang memiliki aktivitas yang benar-benar mendukung brand image dari HarleyDavidson. Hal tersebut dibenarkan oleh WA yang berpendapat sebagai berikut.

"Ya tentu. Banyak kasus yang awalnya para maniak motor coba motor merk A, merk B yang notabene masih motor Jepang dan kemudian karena pengaruh pergaulan dan komunitas beralih ke Harley dan jadi cinta mati. Beberapa teman saya seperti itu, awalnya coba motor jepang dan akhirnya karena pengaruh temantemannya merasa menemukan identitasnya kok di Harley. Dia merasa "klik" nya di Harley." (WA)

Mengutip pemaparan dari IK merek Harley-Davidson mulai dikenal di Indonesia pada masa setelah Perang Dunia ke II yang merupakan kendaraan hasil rampasan perang dari pihak Sekutu di Indonesia. Pada masa itu, Harley-Davidson hanya digunakan oleh kalangan tertentu seperti pejabat negara, petinggi TNI dan Polri dan beberapa masyarakat kelas atas, sehingga secara tidak langsung masyarakat memiliki persepsi yang kuat bahwa Harley merupakan motor yang gagah dan merupakan simbol sukses bagi penghobi motor. Pernyataan tersebut didukung oleh pernyataan WA dan BC yang disampaikan sebagai berikut.

"Kalau menurut saya begini, secara image Harley itu dipersepsikan gagah. Ada kesan tersendiri seperti macho dan nilai historis tersendiri, contohnya dulu Bapak saya punya Harley jadi saya juga mesti punya. Seperti Mas Indro dulu bapaknya polisi dan memang pakai Harley, jadi dari kecil beliau sudah akrab dengan brand Harley. Ya kayak kita dulu dari kecil biasa minum susu dancow dan pakai pasta gigi pepsodent, dan ketika kita sudah dewasa dan punya anak, kita juga mengajarkan hal yang sama. Itu sih yang driver utama di Indonesia yang saya lihat. Ya kalau kita lihat populasi motor tua yang paling banyak ya Harley." (WA)

"Kalau saya bicara begini, kalau kita bicara di Bali dan Jakarta ya secara umum memang ada 2 jenis ya. Yang satu memang ada naik Harley buat semacam 
naikkin gengsi, atau saya naik BMW bukan karena merk nya tapi biar dilihat orang, ada seperti itu. Kedua juga memang ada impian yang belum kesampaian. Impian kecil lah. Contohnya; Wah kalau saya sukses saya harus puya Harley. Harley sebagai simbol kesuksesan. Ya sama seperti sebagian umat muslim yang menjadikan tolak ukur sukses dengan naik haji, ya hampir sama seperti itu lah kirakira." (WA)

"Kalau orang suka motor pasti puncaknya naik Harley. Harley itu sudah legend dari dulu. Dulu waktu saya masih kuliah lihat orang touring Harley rasanya keren sekali tapi baru kesampaian beli Harley umur 40-an.” (BC)

Berdasarkan analisis terhadap hasil wawancara ditemukan bahwa sejarah panjang Harley-Davidson baik secara global maupun di Indonesia menjadikan merek tersebut disimbolkan sebagai gaya hidup berkendara yang memiliki citra freedom, legend, kegagahan dan kesuksesan. Dengan didukung oleh diferensiasi produk yang kuat, hal tersebut memicu terjadinya proses identifikasi merek pada target pasar Harley-Davidson. Identifikasi merek merupakan konstruk sosial yang membuat pelanggan merasa nilai-nilai serta identitas merek Harley-Davidson sebagai bagian dari nilai-nilai yang meraka percaya. Adanya kecocokan nilai-nilai dan identitas antara merek dan pelanggannya menjadikan loyal terhadap merek Harley-Davidson. Pelanggan tersebut pula yang akan menjadi role model bagi masyarakat mengenai gaya hidup berkendara yang ditawarkan Harley-Davidson. Melalui kegiatan pelanggan Harley-Davdison di komunitas, ikatan merek yang terjadi pada pelanggan menjadi semakin kuat dan juga akan memotivasi calon konsumen yang ingin menjadi seperti mereka untuk memiliki Harley-Davidson.

Berdasarkan analisis terhadap hasil wawancara di atas, faktor ikatan merek antara Harley-Davidson dengan anggota komunitas merek tersebut merupakan salah satu Critical Success Factors (CSF) yang berpengaruh signifikan pada ikatan anggota di komunitas Harley-Davidson.

Algesheimer et al. (2005) menemukan bahwa kuatnya hubungan antara pelanggan dengan merek yang diusung berpengaruh positif dan signifikan terhadap motivasi intrinsik pelanggan untuk berinteraksi dan dan bekerja sama dengan sesama anggota komunitas merek yang memiliki pemikiran dan antusiasme yang sama. Interaksi yang terjadi di dalam komunitas merek memberikan berbagai macam manfaat sosial bagi para anggotanya (Muniz dan O'Guinn, 2001). Menurut Dholakia et al. (2009) pelanggan sering kali menjadi anggota komunitas merek dengan alasan untuk mencari bantuan dari anggota lain di komunitas tersebut yang berimplikasi terhadap manfaat sosial yang diterima. Komunitas merupakan wadah struktur interaksi sosial antara individu-individu yang memiliki minat serta ketertarikan yang sama sehingga terbangun hubungan timbal balik yang saling menguntungkan. Interaksi sosial merupakan elemen utama dari eksistensi sebuah komunitas. Berdasarkan pemaparan seluruh narasumber, kegiatan utama dari komunitas Harley-Davidson, antara lain; touring (konvoi Harley-Davidson), kumpul bersama dan juga bakti sosial. Dari pelaksanaan kegiatan-kegiatan tersebutlah interaksi sosial antar anggota bisa terjadi sehingga tiap-tiap anggota akan lebih mengenal satu sama lain. Kegiatan tersebut menjadi seleksi alam bagi para anggota karena tiap-tiap anggota akan mencoba mencari identitas kelompok yang sesuai dengan persepsi pada diri masing-masing anggota. Kecocokan antara 
konsep diri serta nilai-nilai yang dianut oleh komunitas merupakan faktor yang sangat signifikan dalam menumbuhkan ikatan emosional anggota terhadap komunitas yang diusungnya yang berbanding lurus dengan tingkat ikatan anggota di komunitas tersebut. Hal tersebut sejalan dengan penelitian dari Thompson, et al (2018) yang menyatakan bahwa di dalam komunitas merek, produk digunakan dalam konteks memperkuat hubungan sosial antar anggota, sehingga akan membentuk tekanan social bagi anggota komunitas untuk tetap menggunakan merek tersebut. Adapun pendapat narasumber penelitian ialah sebagai berikut.

"Kalau saya, komunitas itu memberikan rasa kebersamaan atau pertemanan yang utama. Makanya sekarang banyak grup-grup Harley kecil ya karena orang hanya cocok dengan orang tertentu saja. Saya cocoknya sama dia ya sudah seperti saudara, tidak formal pergaulannya seperti keluarga. Contohnya kayak saya dengan Willy ya saya tanya, sudah sehat belum? Sudah masuk kantor dia sekarang? Kebersamaan dan kekeluargaan itu yang utama. Kadang-kadang kita kumpul, bawa motor sama keluarga. Tidak dipaksakan itu. Jadi komunitas itu cocok-cocokkan. Misalnya kalau di saya sudah ikut HDCI tapi mau ikut komunitas lain karena memang cocok ya silahkan." (AA)

"Ada beberapa teman seumuran saya yang memang dari muda penggila motor sport seperti kawasaki, ducati, dll. Namun seiring dengan bertambahnya usia, berkeluarga tentunya tidak akan cocok jika tarik gas terus seperti anak umur 21 tahun. Kemudian dia ganti motor dan Harley lah pilihannya. Kenapa Harley? Ya, karena dia lihat teman-temannya sudah ada di komunitas Harley, ya ada kesamaan lah, umur relatif sama, perut sama-sama buncit, temen mainnya sama, obrolannya cocok, bisnisnya cocok. Jadi disamping dia memang merasa fit dengan produk dan brand Harley itu sendiri, dia juga menemukan identitas serta gaya hidup yang cocok dengan komunitas Harley yang diikuti.akhirnya dia jadi loyal dengan Harley." (WA)

Fenomena tersebut sejalan dengan Tajfel (1981:255) yang berpendapat bahwa identitas sosial (social identity) adalah bagian dari konsep diri seseorang yang berasal dari persepsi mereka mengenai keanggotaan dalam suatu kelompok sosial bersamaan dengan signifikansi nilai dan sisi emosional dari keanggotaan tersebut. Kecocokan antara konsep diri serta nilai-nilai yang dianut oleh komunitas merupakan faktor yang sangat signifikan dalam menumbuhkan ikatan emosional anggota terhadap komunitas yang diusungnya yang berbanding lurus dengan tingkat ikatan anggota di komunitas tersebut.

Manfaat sosial lainnya yang didapat oleh anggota komunitas HarleyDavidson ialah rasa bangga yang muncul ketika menggunakan dan menjadi anggota komunitas Harley-Davidson. Berdasarkan hasil wawancara adapun faktor spesifik yang berpengaruh pada rasa bangga tersebut ialah nilai historis merek HarleyDavidson merupakan faktor utama yang memicu rasa bangga. Harley-Davidson diibaratkan sebuat benda koleksi yang tidak semua orang bisa memilikinya karena tiap motor memiliki sejarahnya masing-masing. Selain itu ada faktor prestise yang melekat pada merek Harley-Davidson yang tidak dapat dipungkiri juga membanggakan bagi anggota komunitas Harley-Davidson, seperti yang dungkapkan oleh narasumber berikut. 
"Jadi di Harley tua itu ada suatu kebanggan tersendiri. Jadi kasarnya gini, lu punya duit tapi belum tentu bisa beli. Itu alasan pertama. Yang kedua kita lihat perjalanan belinya, bagaimana dia beli awalnya dari rongsokan, wah ini shock nya gak ada, mesti ngerakit, banyak sparepartnya yang mesti dicari, hunting sparepart, merakit ya journey nya lah hingga motor itu bisa jadi." (WA)

"Nah ini mulai pride nya ketika fanatisme di Amerika berlebihan. Nah ini sebetulnya yang mulai Amerika juga. Misalnya ketika Micahel Jackson ulang tahun diberikan hadiah Harley Davidson Ultra Classic. Dan sebelum itu Harley Davidson melansir gak kurang dari 100 selebritis dunia yang pakai Harley-Davidson." (IK)

"Saya beri contoh lagi. Anda pernah di Jogja kan? Coba lihat disana ada motor Harley-Davidson tua, dicari orang gak? Dicari orang kan. Artinya apa? Ada motor Jepang gak yang dicari, gak ada kan. Justru itu yang saya bilang. Produkproduk Harley walaupun sudah oldschool. Saya bilang oldschool. Itu tetap dicari kenapa? Karena mereka terkenal pada jamannya. Yang dipakai Dean Martin pada tahun 50 itu harganya bisa 1 Miliar ya. Jadi ada legendnya. Kadang-kadang gak waras gitu, motor sudah tua dan jelek harganya 1 Miliar." (SM)

Adanya kesamaan dari identitas sosial serta nilai-nilai yang dianut oleh setiap anggota menciptakan ikatan emosional yang kuat antar anggota komunitas. Hal tersebut merupakan faktor utama yang menentukan soliditas komunitas tersebut. Berdasarkan analisis terhadap hasil wawancara, dapat disimpulkan bahwa faktor sosial merupakan salah satu Critical Success Factors (CSF) yang berpengaruh pada ikatan pelanggan terhadap komunitas Harley-Davidson.

Anggota komunitas Harley-Davidson tentunya memiliki pengalaman dan keahlian yang baik yang bisa dibagikan dengan anggota lainnya. Pada umumnya informasi tersebut dapat berupa rekomendasi produk, permasalahan yang sering terjadi pada produk beserta solusinya dan tips-tips umum dalam pelangganan produk.

Berdasarkan hasil wawancara terhadap para narasumber ditemukan bahwa komunitas Harley-Davidson merupakan wadah untuk pembelajaran dan pertukaran informasi mengenai produk-produk Harley-Davidson yang disampaikan dalam pernyataan berikut. Bahkan komunitas juga akan membantu pengurusan surat-surat apabila motor yang dimiliki masih belum memiliki surat resmi. Para anggota komunitas pun akan dibantu untuk mempelajari teknik mengendarai HarleyDavidson yang baik dan benar sesuai dengan pernyatan dari narasumber WA dan BC berikut.

"Ya tapi akhirnya balik-balik komunitas akan membantu member yang motornya masih belum ada surat kita bantu. Motor yang gak ada suratnya kita jual terus kita bantu carikan motor yang ada suratnya, jadi aman." (WA)

"Ya jadi di HOG memang diajarkan safety riding, kita tahu teknik self-riding, tahu teknik touring." (BC)

Selain mengenai rekomendasi produk dan juga teknik berkendara, para anggota komunitas pun seringkali berdiskusi mengenai teknik perawatan dan juga modifikasi motor Harley-Davidson. AA menyampaikan bahwa banyak komunitas Harley-Davidson di luar HOG yang bekerjasama dengan bengkel-bengkel HarleyDavidson diluar milik authorized-dealer. Beliau pun bahkan banyak belajar 
mengenai perawatan Harley-Davidson pada bengkel rekanan komunitas, seperti pada penuturannya berikut ini.

"Ya tentu. Tapi sebenarnya kalau saya mekanik memang bisa, cuma waktu yang gak ada. Saya punya mekanik andalan, anak buahnya Pak Badera, bapaknya Ketut Bemo. Dulu punya anak buah kesayangan dia, anak buah yang paling lama, sampai bengkelnya tutup, anak buahnya masih nge-bengkel. Itu dah yang saya ajak, saya belajar teorinya, prakteknya dia saya ajak. Jadi itulah, kebetulan dulu saya sekolah Teknik mesin jadi ngertilah sedikit-sedikit, gitu." (AA)

Bahkan menurut pemaparan salah seorang narasumber pada wawancara kelompok BC mengungkapkan temuan bahwa seringkali terjadi diskusi bahkan saling adu kreativitas dalam memodifikasi sepeda motor Harley-Davidson masingmasing, yang diungkapkan dalam pemaparan berikut.

"Sering, sering itu terjadi. Kadang-kadang kita juga saling ejek modifikasi teman "apa ini motornya masih pakai ban donat (ban size normal)". Padahal pakai ban size 21 " atau 23" sudah pasti tidak nyaman dipakainya (tertawa). Ya sama kayak mobil kalau diceperin kan keren, tapi kalau dipakai kayak kuda rasanya. Ya tapi tergantung komunitasnya juga, kadang ada memang komunitas yang suka modifikasi, ada juga yang hanya suka touring." (BC)

Hasil wawancara tersebut sejalan dengan penelitian dari Dholakia et al. (2009) yang menyebutkan komunitas merek memberikanmanfaat fungsional yang pada umumnya didapat dalam bentuk informasi-informasi penting terkait produk dan merek yang berasal dari anggota lain dari komunitas merek tersebut. Fournier (2009) juga menambahkan bahwa komunitas Harley-Davidsnon tidaklah berfokus untuk meningkatkan penjualan unit, melainkan untuk membantu pelanggan dalam memenuhi kebutuhannya sehingga pelanggan akan menjadi loyal. Komunitas Harley-Davidson sangat memfasilitasi anggotanya untuk melakukan pertukaran informasi baik berupa rekomendasi produk, forum jual-beli motor dan sparepart, diskusi mengenai teknik berkendara dan juga modifikasi produk. Pertukaran informasi tersebut akan membantu pelanggan dalam baik dalam menentukan keputusan pembelian maupun proses konsumsi dari produk tersebut. Hal ini akan menghilangkan kecemasan pelanggan yang disebabkan oleh kurangnya informasi terhadap produk. Pelangganpun akan merasa terbantu dan nyaman dengan menjadi anggota komunitas merek, hal tersebut akan membuat pelanggan merasa terikat dengan komunitas mereka.

Dholakia et al. (2004) menambahkan bahwa faktor hiburan dari komunitas merek dapat berupa manfaat relaksasi dan rasa senang yang dipicu dari interaksi antar anggota dalam kegiatan yang diinisiasi oleh komunitas merek. Selain itu, faktor hiburan yang didapat oleh pelanggan dapat pula berasal dari sensasi pengalaman menggunakan produk secara bersama-sama dengan anggota komunitas merek. Berdasarkan hasil wawancara, ditemukan fakta bahwa sebagian besar komunitas Harley-Davidson yang eksis di Indonesia merupakan komunitas hobi yang lahir karena adanya hobi yang sama dari para pengguna Harley-Davidson yakni mengendarai sepeda motor Harley-Davidson seperti yang disampaikan oleh narasumber AA, WA, dan BC sebagai berikut. 
"Untuk motivasi utama ya memang mencari hiburan/hobi. Komunitas tidak akan bertahan jika tidak ada keduanya itu. Jadi yang paling penting itu menyalurkan hobi yang kedua baru relationship." (AA)

"Kalau saya kan memang hobi, suka adventure nya, senang pretelin mesinnya, naik motor pun dipelajari semuanya termasuk mesin, bagaimana pakainya hingga sejarahnya kan gitu ya, tujuannya murni karena hobi." (WA)

"Namun jika yang ditanya ialah motivasi kami untuk menjadi anggota HOG yang pertama ialah adanya kesamaan hobi naik motor dan juga pertemanan jadi kita bisa kumpul-kumpul bersama teman-teman mengisi waktu senggang dengan menaiki Harley-Davidson." (BC)

Penulis menggali lebih dalam mengenai faktor-faktor hiburan spesifik ketika mengendarai Harley-Davdison yang disampaikan dalam pernyataan berikut.

"Selain itu naik motor tua (Harley klasik) ada seninya sendiri, ya mogoknya lah, businya lah. Jadi itu akan jadi memori unik sendiri buat saya. Jadi kalau ditanya, apakah enak naik motor tua ya jawabannya enggak. Buat saya lebih ke seni nya ya, ada art atau value yang tidak bisa dibeli. (WA)

"Karena mengendarai motor Harley itu suatu kesenanngan, enak sekali ya enak sekali, kita dengerin suaranya sudah kangen gitu. (tertawa). Nah itu kita sudah lebih dari saudara. Kita bersenda gurau dari pagi sampai sore, nginap di hotel bareng." (SM)

"Karena hobi. intinya nyaman, jadi kalau sudah nyaman pasti kita senang apapun itu. Jadi kalau ada yang bilang suka Harley, ada waktu, ada uang tapi kalau dia tidak suka naik motor ya capek ah. Tapi kalau sudah hobi ya kayak ini (menunjuk ke temannya) sendirian dari Aceh kesini (Bali;Red) (tertawa). Coba kita pikir orang gila apa sendiri jalan-jalan naik motor jauh gitu. Coba kita pikir orang gila apa kayak gitu? Naik motor mahal-mahal, kepanasan terus kehujanan. Tapi itu yang seru, disaat motor teman rusak di perjalanan pun kita masih bisa happy, bukan ngetawain tapi jadi cerita lucu buat kita, wah kemarin motornya rusak, apa motornya keserempet. Itu yang bikin kebersamaan kita makin erat. Jadi ada cerita buat dibawa pulang. Mungkin karena selama naik Harley adrenalin kita itu keluar, kalau naik Harley kan harus fokus gak boleh meleng sama sekali, sekian detik meleng sudah nyawa taruhannya. Sudah lewat.” (BC)

Menurut narasumber WA, SM, dan BC memaparkan bahwa mengendarai Harley-Davidson memberikan pengalaman baru yang unik ketika menjelajah berbagai lokasi saat touring bersama teman-teman. Pengalaman tersebut menjadi sebuah memori berharga bagi anggota komunitas. Pengalaman yang menyenangkan tersebut bahkan menjadi adiksi bagi para pelanggan HarleyDavidson. Bahkan banyak yang menjadikan kegiatan touring tersebut layaknya suatu kebutuhan seperti pernyataan narasumber SM dalam kesempatan wawancara bersama beliau sebagai berikut.

"Disitu kita ketemu teman-teman, bercanda, berkenalan, saling bertegur sapa dulu awalnya. Baru kemudian kita tahu dengan adanya teman-teman tadi. Pertama belum touring dulu, baru keliling-keliling dan berkenalan, sudah lama baru mereka cerita touring ya saya ikut. Sampai akhirnya itu kita dalam posisi kalau gak touring seperti addicted, seperti orang merokok." (SM) 
Berdasarkan analisis terhadap hasil wawancara di atas, faktor hiburan merupakan faktor utama yang mempengaruhi ikatan pelanggan terhadap komunitas Harley-Davidson. Hal tersebut terbukti dengan pernyataan para narasumber yang menyatakan bahwa adanya kesamaan hobi merupakan motivasi utama pelanggan Harley-Davidson membentuk komunitas Harley-Davidson. Seluruh narasumber sepakat bahwa kegiatan touring menjadikan pengalaman menggunakan produk Harley-Davidson menjadi hal yang adiktif. Adiksi terhadap pengalaman tersebut menyebabkan setiap pelanggan Harley-Davidson selalu mengadakan touring dan menceritakan pengalaman menyenangkan tersebut kepada orang lain yang tanpa disadari akan menjadi words of mouth (WoM) bagi merek Harley-Davidson. Dalam kegiatan touring pula terbentuk ikatan emosional antara pelanggan dan komunitas merek yang diusung.

Wirtz et al. (2013) memaparkan bahwa banyak perusahaan yang menawarkan insentif yang bersifat moneter misalnya poin loyalitas/keanggotaan, undian, potongan harga bagi para anggota mereka untuk meningkatkan partisipasi dan ikatan pelanggan di dalam komunitas yang dibentuk. Berdasarkan hasil wawancara, ditemukan bahwa dealer Harley-Davidson memberikan insentif moneter berupa potongan harga bagi anggota Harley Owners Group (HOG) dan juga dukungan teknis ketika mengadakan touring yang dipaparkan dalam pernyataan berikut.

"Oh pasti, contohnya seperti pemberian diskon. Atau misalnya jika kita mau touring kita koordinasi dengan mereka bisa bantu backup gak. Ya timbal baliknya ya kita juga beli barang dia. Ya ini semua sih hanya masalah bisnis ya, yang mana menguntungkan tentu akan di endorse. Ya kasarnya kalau kamu beli motor ditempat lain, beli sparepart di tempat lain ya gak bisa lah minta di endorse. Gak menguntungkan dong. Ya sepanjang menurut mereka menguntungkan, mereka bantu kok, ya seperti diskon, pengadaan sparepart, dan lain-lain. Ya menurut saya sah-sah saja." (WA)

"Potongan harga. Kita boleh ikut acara apapun yang diadakan oleh dealer. Bahkan sampai, apa ya, kopi di dealer ada yang hanya untuk member. Di dealer biasanya ada kayak semacam kopi atau cemilan itu hanya untuk HOG, bukan untuk yang lain, kayak gitu. Pembelian sih gak usah ngomong. Bahkan untuk merchandise yang khusus HOG disiapin untuk mereka dengan harga yang relatif lebih murah walalupun orang lain boleh beli."(IK)

Dalam wawancara kelompok yang diadakan terhadap pengurus HOG-Bali Chapter menyampaikan bahwa dealer Harley-Davidson memberikan kompensasi berupa kantor operasional dan dukungan dana untuk setiap pembelian motor Harley-Davidson baru yang digunakan untuk mendukung operasional komunitas yang disampaikan dalam pernyataan berikut ini.

"Jadi setiap motor yang laku ada kompensasi yang diberikan ke kita. Jadi orang yang beli Harley baru langsung member satu tahun, setalah itu perpanjang sendiri." (BC)

Berdasarkan keterangan AA dan BC ditemukan bahwa faktor ekonomi berupa dukungan finansial dan insentif moneter dari dealer tidak memberikan pengaruh signifikan terhadap ikatan pelanggan Harley-Davidson terhadap komunitas Harley-Davidson dalam jangka panjang. Berikut pernyataan dari narasumber-narasumber tersebut. 
"Kita, walau dealer itu masih buka atau tutup gak ada pengaruhnya, orang kita sudah hobi. Dia mau tutup ya tutup aja, cara lain masih banyak.

Pernyataan tersebut senada dengan pernyataan dari BC yang memberikan pernyataan sebagai berikut.

"Jadi begini, awalnya pasti ada dealer dia. Kemudian karena perubahan kondisi, HOG sudah jalan tapi dealer berhenti. HOG kan harus tetap eksis, harus tetap jalan tanpa dealer." (BC)

"Ya itulah fungsi marketing tools dari komunitas. Ya balik lagi untuk urusan hobi, pasti komunitas itu sangat berpengaruh. Kalau hanya kebutuhan basic ya gak. Karena kalau sudah hobi, rupiah itu nomor sekian." (WA)

Bahkan menurut AA dan IK mengungkapkan bahwa insentif menoter yang diberikan komunitas atau dealer kurang kompetitif dibandingkan retailer non dealer seperti disampaikan sebagai berikut.

"Bisa cari sparepart paling deket di Australia. Ya paling lama 1 minggu sudah sampai barangnya. Motorpun banyak yang masuk dari sana, ya motor yang bodong." (AA)

"Ngapain saya beli, kalau lebih murah beli dari luar? Bisa di ebay atau segala macam, saya lebih murah dari situ." (IK)

Berdasarkan analisis terhadap hasil wawancara di atas, insentif moneter dari komunitas bukanlah faktor yang berpengaruh pada ikatan pelanggan pada komunitas Harley-Davidson. Namun temuan tersebut sejalan dengan pendapat Garnefeld, et al (2012)menyebutkan bahwa insentif moneter hanya memberikan pengaruh yang signifikan terhadap partisipasi pelanggan yang bersifat jangka pendek, seperti pada peningkatan partisipasi dari pelanggan pasif di komunitas merek tersebut.

Penelitian yang dilakukan Wirtz et al. (2013) memaparkan bahwa implementasi dari keempat CSF tersebut akan berujung pada kesuksesan komunitas merek. Kesuksesan sebuah komunitas merek adalah ikatan yang tejadi antara pelanggan dan komunitas merek tersebut. Namun Wirtz et al. (2013) menambahkan bahwa implementasi dari keempat CSF tersebut perlu didukung oleh beberapa aspek pendukung, yakni; aspek produk, aspek pelanggan, dan aspek situasi komunitas. Sejalan dengan penelitian tersebut, hasil analisis pada transkrip wawancara menunjukkan bahwa terdapat fakta menarik yakni ditemukannya beberapa aspek diluar CSF yang mendukung efektifitas dari CSF. Adapun kedua aspek pendukung tersebut adalah produk dan pelanggan.

AA dan SM memaparkan bahwa Harley-Davidson memiliki produk dengan kualitas baik dan memiliki diferensiasi yang kuat dibandingkan merek produk sejenis.

"Apa ya yang mesti kita bilang? Karena dari nama besar dan nilai historisnya saja sudah beda. Kalau Harley kan 1903 sampai sekarang. Kelengkapan motornya juga, kelengkapan aksesorinya, kayaknya punya nilai lebih dari motor lain. Tapi kalau kenyamanan mungkin aja kalah. Kalau dari merek, ya pasti merk lain kalah. Kebanggan yang sukar dimengerti. (AA)

"Jadi gini, Harley itu kan legend ya jadi bukan sekedar merek lagi. Jadi kenapa Harley-Davidson? satu itu nama besarnya, kedua memang bentuknya, desainnya, mesinnya itu memang keren. Yang ketiga, hanya motor Harley- 
Davidson yang variasinya sangat banyak, jadi maksudnya kalau kita mau spionnya beda bisa ganti, kita mau warnanya ganti bisa ganti. Itu yang tidak bisa digantikan oleh DEB, Ducati. Triumph juga sama, Triumph kan motor eropa sama kayak BMW, ya sama. Saya punya motor Triumph, BMW, tidak bisa saya apa-apain, sudah gitu aja." (SM)

"Kalau menurut saya sih suara ya. Itu kan sampai dipatenkan model suara knalpotnya. Motor lain tidak bisa tiru itu. Kalau mau cari gagah ya suara Harley lah yang paling gagah. Merek lain coba bikin suara bledag-bledug tetap tidak bisa seperti Harley. Jadi kalau memang ingin menimbulkan kesan gagah ya pasti pilih Harley. Tapi banyak juga pengendara yang bisa saya katakan priyayi, mereka lebih prefer pilih BMW. Di Indonesia menurut saya kedua merek motor yang kuat ialah Harley dan BMW." (WA)

Berdasarkan variabel produk, AA dan SM menjelaskan bahwa HarleyDavidson memilki keunggulan komparatif berupa desain, kelengkapan sparepart dan aksesoris, kemudahan modifikasi dansuara mesin. Pelanggan Harley-Davidson dapat menggunakan aksesoris berkendara misalnya slayer, rompi, jaket, badge, dan lain-lain untuk menunjang penampilan berkendara mereka. Dengan desain produk yang klasik dan kemudahan untuk dimodifikasi membuat produk Harley-Davidson mampu memberikan citra yang sesuai dengan keinginan pelanggannya dan ditambah dengan kegarangan suara mesin Harley-Davidson yang menambah citra urakan dan kegagahan yang dimiliki oleh Harley-Davidson. Desain produk, suara mesin dan penampilan berkendara pelanggan secara sinergis membentuk citra urakan dan gagah pada merek tersebut. Namun SM menambahkan bahwa produk yang harus ditunjang oleh citra premium dari produk tersebut. Tanpa kedua hal tersebut, beliau menyampaikan bahwa implementasi komunitas merek akan menjadi kurang efektif, seperti pernyataan beliau berikut ini.

"Ya artinya produknya dulu bagus, disenangi walaupun mahal, nah baru habis itu terbentuk komunitas. Nah jadi saya bisa bayangin gini, ada namanya merk motor Royal Enfield dari India. Motornya Inggris tapi sekarang diproduksi di India. Harganya murah kira-kira sekarang 70 jutaan tapi bentuknya bagus. Dia mencoba untuk membentuk komunitas, ya gak bisa juga, karena pride nya gak ada. Gak bisa mas." (SM)

Menurut Babin et al. (1994) kebutuhan yang dirasakan konsumen dibedakan berdasarkan kepada manfaat yang diharapkan dari pembelian dan pelangganan produk. Pertama adalah kebutuhan utilitarian yang mendorong konsumen membeli produk karena manfaat fungsional dan karakteristik objektif dari produk tersebut. Kedua adalah kebutuhan ekspresif atau hedonik) yaitu kebutuhan yang bersifat psikologis misalnya rasa puas, gengsi, emosi dan perasaan subjektif lainnya. Kebutuhan ini seringkali muncul untuk memenuhi tuntutan sosial dan estetika.

Narasumber WA menambahkan bahwa komunitas merek akan sangat efektif apabila digunakan pada produk yang keputusan pembeliannya dilakukan atas dasar pemenuhan kebutuhan ekspresif atau hedonis misalnya hobi,gaya hidup, gengsi dan perasaan subjektif lainnya, berikut pernyataan beliau.

"Ya kebetulan saya senang riset dan setelah kita diskusi keputusan saya begini; komunitas akan menjadi marketing tools yang baik apabila purchasing decision dilakukan berdasarkan hobi atau kebutuhan tertentu. Ada driver khusus 
tertentu. Namun apabila produk itu dijual sebgai pemenuhan kebutuhan transportasi, gak usah pakai komunitas." (WA)

"Ya itulah fungsi marketing tools dari komunitas. Ya balik lagi untuk urusan hobi, pasti komunitas itu sangat berpengaruh. Kalau hanya kebutuhan basic ya gak. Karena kalau sudah hobi, rupiah itu nomor sekian. Betul ya?" (WA)

Dalam sesi wawancara WA memaparkan bahwa untuk memenuhi kebutuhan ekspresif atau hedonik tersebut akan memicu motif pembelian irasional yang akan mengesampingkan faktor harga dari produk demi memaksimumkan kepuasan subjektif dari konsumen.

Dengan kualitas produk yang baik serta kesan premium yang ingin ditampilkan, tentunya akan membuat harga jual dari Harley-Davidson tergolong tinggi. Hal tersebut tentunya harus disesuaikan dengan profil ekonomi dari target pasar agar tetap memiliki daya beli terhadap produk Harley-Davidson. Tingginya biaya untuk mengakomodasi hobi berkendara Harley-Davidson diakui narasumber AA dan BC dalam pernyataan beliau berikut ini.

"Ya Harley memang hobi yang tergolong mahal. Harga sparepart pun juga mahal. Tapi yang namanya hobi ada saja caranya untuk memenuhinya. Contohnya saya. Saya kan PNS, tapi kalau duit buat hobiya juga berasal dari hobi saya ini. Dulu kan gampang cari duit di Harley ini, kita jadi penghubung kan kita dapat fee. Terus kita kirim motor ke luar daerah dan ngurusin itu sama teman-teman yang lain di daerah tujuan juga dapat fee. Masih sedikit orang yang mengerti urusan itu jadi masih gampang dapat duit. Ya uang dari hobi pakai untuk hobi lagi kembali." (AA)

"Tapi yang kedua ya ini (memberikan gesture yang berarti uang), gaya hidup seperti ini kan perlu biaya tinggi (tertawa). Easy come, easy out." (BC)

Berdasarkan analisis terhadap hasil wawancara dalam penelitian ini dapat disimpulkan bahwa implementasi strategi komunitas merek hanya efektif digunakan pada produk-produk tertentu yang memenuhi beberapa aspek berikut; (1) Produk bersifat premium dengan diferensiasi yang sangat kuat dibanding competitor, (2) Keputusan pembelian dimotivasi oleh pemenuhan kebutuhan ekspresif atau hedonis seperti; gaya hidup, hobi, gengsi, dan lain-lain, (3) Produk ditujukan pada target market yang spesifik dengan profil demografi dan psikografi yang sesuai dengan nilai-nilai yang ditawarkan oleh merek. Ketiga aspek di atas yang diseinergikan dengan implementasi CSF sesuai yang terlampir Gambar 1 diharapkan mampu memberikan dampak signifikanpada kesuksesan komunitas merek sebagai instrumen untuk memperkuat ikatan emosional antara pelanggan dengan merek yang diusung.

Berdasarkan hasil penelitian ditemukan bahwa implementasi strategi komunitas merek yang dilakukan oleh Harley-Davidson telah memenuhi kriteria CSF dirumuskan dalam penelitian yang dilakukan oleh Gummerus et al. (2012) dan Wirtz et al. (2013) dan sukses mencapai tujunannya. Kesuksesan sebuah komunitas merek didefinisikan sebagai ikatan yang tejadi antara pelanggan dan komunitas merek tersebut yang bisa diukur dari beberapa indikator, antara lain; komitmen dan minat untuk terus berpatisipasi di komunitas merek, kepuasan dan loyalitas pelanggan terhadapa merek, ikatan pelanggan terhadap perusahaan, peningkatan ekuitas merek 
Terjadinya ikatan pelanggan dapat diindikasikan dengan tumbuhnya komitmen serta minat untuk berpartisipasi di komunitas merek dalam jangka panjang. Fenomena tersebut sesuai dengan fakta yang diungkapkan narasumber AA dalam pernyataan beliau sebagai berikut.

"Ukuran sukses itu tidak tergantung dari jumlah anggota tapi ya dari organisasinya bagaimana. Misalnya kriterianya ya mungkin gak pernah dikomplain, tertib, ada programnya, ya ada prestasinya. Sedikit pun misal cuma 30 orang kita ya jalan kita, tidak masalah, yang penting bisa solid, bisa ada rasa kebersamaan, bukan baru ada acara baru ramai, gak ada acara sepi lagi, gak eksis. Bukan anggota yang muncul dan hilang, kalau kita anggota terdaftar semua dari pusat." (AA)

Berdasarkan pernyataan AA, ukuran sukses sebuah komunitas bukan berdasarkan jumlah anggota, melainkan dari komitmen anggota untuk bisa terus berpartisipasi di komunitas merek. Hal tersebut lah yang berimplikasi pada rasa kebersamaan, soliditas dan eksistensi komunitas Harley-Davidson dalam jangka panjang. Narasumber BC dan SM menambahkan bahwa komitmen dan minat untuk terus berpartisipasi di komunitas merek disebabkan adanya kebutuhan anggota komunitas yang selama ini diakomodasi oleh komunitas, berikut pernyataan beliau.

"Begitu saya coba mengendarai sendiri mau kemana pergi kan bingung tu? Pertama-tama kita kembali ke dealer. Naik motor ke dealer, kita lihat ada baju disitu, kita beli. Disitu kita ketemu teman-teman, bercanda, berkenalan, saling bertegur sapa dulu awalnya. Baru kemudian kita tahu dengan adanya teman-teman tadi. Pertama belum touring dulu, baru keliling-keliling dan berkenalan, sudah lama baru mereka cerita touring ya saya ikut. Sampai akhirnya itu kita dalam posisi kalau gak touring seperti addicted, seperti orang merokok. (SM)

SM menyatakan bahwa kegiatan touring merupakan kegiatan utama dalam gaya hidup berkendara yang ditawarkan oleh Harley-Davidson. Kegiatan tersebut bahkan sudah bersifat adiktif bagi anggota komunitas, sehingga anggota komunitas pun memerlukan wadah untuk mengakomodasi kebutuhan tersebut yakni sebuah komunitas Harley-Davidson yang solid.

Berdasarkan penuturan kedua narasumber tersebut disimpulkan bahwa kegiatan touring (faktor hiburan) dan relasi pertemanan (faktor sosial) menjadi dua faktor utama yang membuat pelanggan Harley-Davidson memiliki komitmen dan minat yang kuat untuk berpartisipasi di komunitas Harley-Davidson.

Komunitas Harley-Davidson merupakan organisasi yang memberikan dukungan bagi pengguna Harley-Davidson untuk menyalurkan hobi dan gaya hidup berkendara Harley-Davidson. Kinerja komunitas Harley-Davidson tentunya dapat diukur dari tingkat kepuasan para anggota komunitas tersebut. Tingkat kepuasan yang baik akan berimplikasi positif terhadap tingkat loyalitas dari pengguna merek Harley-Davidson.

Berdasarkan hasil wawancara, keseluruhan narasumber menyatakan bahwa pengguna Harley-Davidson memiliki tingkat kepuasan dan loyalitas yang sangat tinggi. Pelanggan Harley-Davidson tidak hanya sekedar loyal, bahkan mencapai level fanatisme yang tinggi. Bahkan dalam level yang ekstrim, pelanggan HarleyDavidson menjadikan nilai-nilai yang dianut mengenai merek tersebut menjadi sebuah "agama" bagi mereka. Berikut pernyataan dari para narasumber. 
"Ya betul, produk apa yang bisa begitu saya juga gak tahu. Cuma Harley saja setahu saya. Jadi namanya sudah bukan brand loyalty tapi brand religion." (SM)

"Tapi kalau saya lihat sih antara dealer dengan kecintaan kita kepada Harley tidak ada hubungannya. Contohnya sekarang nih Mabua kan tutup. Ya kadangkadang kita juga walau dibilang sebagai marketing tools, kita tidak merasa menjadi marketing tools. Karena kita ini kan sebenarnya customernya dealer. Orang kita beli motornya bayar. Nah cuman, nah hebatnya kalau anda mau buat penelitian itu justru anda harus mengupas lebih banyak tentang strategi marketingnya Harley itu sangat hebat. Orang mau beli dan pakai bajunya Harley-Davidson seharga 1,5 juta dan orang itu mau menjadi marketing atau salesnya secara berjalan ketika touring atau berpergian." (SM)

Narasumber SM menyatakan bahwa loyalitas dari pelanggan HarleyDavidson telah berevolusi menjadi sebuah brand religion. Para pelanggan HarleyDavidson tidak hanya memiliki komitmen yang kuat dalam membeli dan menggunakan produk Harley-Davidson, melainkan juga melakukan word of mouth untuk menyebarkan gaya hidup berkendara mereka. Bahkan untuk mendukung citra kebebasan, kegagahan dari Harley-Davidson, pelanggan Harley-Davidson juga mengenakan aksesori khas Harley-Davidson seperti rompi, badge, slayer, baju dan bahkan mentatto tubuhnya dengan logo Harley-Davidson seperti yang disampaikan oleh narasumber WA dan IK berikut ini.

"Lain halnya kayak Mas Indro ujung ke ujungnya ya Harley. Mungkin jempolnya kalau bisa Harley ya Harley, nama anaknya aja Harley (tertawa). Kalau Pak Gung Wir ditanya, pasti Harley jawabannya. Tapi kalau ditanya ke beliau kan saya dekat sekali ya, "Gung, payu ne ngalih Harley?" (re: Gung jadi mau cari Harley) dia bilang ya " jeg gampang” Ya karena dia imagenya sudah orang Harley, Gung Harley nama anaknya. Dipanggil dimana-mana Gung Wir Harley ya otomatis sudah terendorse lah (tertawa), imagenya sudah menempel." (WA)

Narasumber WA menyampaikan bahwa banyak rekan beliau yang memang sudah mencapai level fanatisme yang tinggi sehingga identitas Harley-Davidson melekat pada identitas pribadi orang tersebut. WA menambahkan bahwa rekan beliau yakni AA dan IK bahkan menamai anaknya dengan kata Harley. Fanatisme tersebut diakui pula oleh IK seperti pernyataan IK berikut ini.

IK memaparkan bahwa ada adagium yang menyatakan bahwa "Sekali anda mencintai Harley-Davidson maka Harley-Davidson akan mengalir di darah anda." Kejadian yang dialami IK juga dialami oleh narasumber lain seperti WAyang menceritakan bahwa kegemarannya akan Harley-Davidson berawal dari kegemaran orang tua beliau, berikut pernyataan dari narasumber.

"Kalau menurut saya begini, secara brand image Harley itu dipersepsikan gagah. Ada kesan tersendiri seperti macho dan nilai history tersendiri, contohnya dulu Bapak saya punya Harley jadi saya juga mesti punya. Seperti Mas Indro dulu bapaknya polisi dan memang pakai Harley, jadi dari kecil beliau sudah akrab dengan brand Harley. Ya kayak kita dulu dari kecil biasa minum susu dancow dan pakai pasta gigi pepsodent, dan ketika kita sudah dewasa dan punya anak, kita juga mengajarkan hal yang sama. Namun yang terpenting bahwa di komunitas itu bisa memenuhi kebutuhan anggotanya. Misalnya untuk menjalankan hobi bersama, touring dan bersosialisasi. Itu sih yang driver utama di Indonesia yang saya lihat. 
Ya kalau kita lihat populasi motor tua yang paling banyak ya Harley, karena komunitasnya juga sangat kuat dan solid." (WA)

Pernyataan narasumber tersebut sesuai dengan penelitian dari Fournier (2009) yang menyebutkan bahwa komunitas yang kuat tidak hanya dibentuk dari reputasi merek, melainkan lebih fokus kepada bagaimana komunitas memahami anggotanya. Menempatkan ekuitas merek menjadi prioritas kedua mungkin sangat sulit bagi pemasar, namun apabila hal yang menjadi tujuan adalah untuk membentuk komunitas merek yang kuat tentunya memahami anggota komunitas merupakan prioritas utama.

Komunitas merek merupakan instrumen yang digunakan oleh perusahaan untuk menjalin hubungan yang erat dengan pelanggannya. Komunitas merek yang sukses akan mampu bersinergi dengan pelanggannya. Salah satu bentuk sinergi yang dilakukan ialah dengan memberdayakan komunitas merek sebagai sumber informasi dalam pengembangan produk. Berdasarkan hasil wawancara, HarleyDavidson Motor Company telah memanfaatkan komunitas Harley Owners Group (HOG) sebagai informan dalam riset pasar. Berikut penjelasan dari narasumber.

"Diundang, kita selalu diundang. Dulu contohnya waktu di Malaysia itu kan ada Harley listrik, itu kita diundang.Iya disitu kita dimintai pendapat mengenai produknya, enak gak dipakai?Bagaimana komentarnya?" (BC)

"Ya memang kita di HOG sering mendapat kuesioner ataupun undangan launching produk baru ya kalau dibilang mengutarakan pendapat ya semacam itulah. (SM)

"Saya punya member card khusus untuk dapat diskon di semua dealeryang gak boleh ditolak, saya dapat majalah khusus, dapat badge khusus. Saya dapat email khusus, dapat kuesioner khusus, itu banyak orang gak ngerti. (WA)

Menurut BC, SM, WA, Harley-Davidson Motor Company memberikan kesempatan bagi pelanggan Harley-Davidson untuk memberikan kontribusi berupa ide, kritik dan saran sebagai informasi yang berguna bagi Harley-Davidson dalam melakukan inovasi. Hal tersebut membuat pelanggan semakin merasa dihargai oleh perusahaan dan inovasi yang dilakukan pun menjadi sesuai dengan kebutuhan pasar.

Strategi komunitas merek yang berhasil ditandai dengan terbentuknya loyalitas pelanggan dan juga kesediaan pelanggan menjadi brand advocate bagi merek yang diusung oleh komunitas tersebut. Komunitas merek yang berhasil akan menjelma sebagai marketing tools yang memiliki dampak yang signifikan pada ekuitas merek yang diusung.

Sejalan dengan penrnyataan di atas, AA berpendapat bahwa komunitas Harley-Davidson memiliki peran dalam memperkenalkan gaya hidup berkendara Harley-Davidson kepada masyarakat Indonesia dalam pernyataan beliau berikut ini.

"Sejarahnya kenapa saya buat grup motor adalah ketika lihat FFI (Festival Film Indonesia) tahun 1981 atau 1982, jadi saya nonton dan berpikir "wih gagah sekali naik Harley Ya!". Jaman itu masih jaman saya preman-premannya jaman dulu. Ya waktu itu teman saya Pak De Gobleg, ada Lolot dulu masih ada komunitas Armada Racun namanya. Itu grup paling top dulu, di depan rumah saya ini ngumpulnya." (AA) 
Berdasarkan pendapat AA di atas, dapat dijustifikasi bahwa awal ketertarikan AA terhadap produk Harley-Davidson dipengaruhi oleh adanya komunitas motor yang eksis pada waktu itu. Atribut penampilan dari pengguna Harley-Davidson serta performa Harley-Davidson baik secara audio-visual maupun spesifikasi teknis produk membuat AA mengenal produk Harley-Davidson dan merasakan identitas kegagahan dari Harley-Davidson.

Berdasarkan hasil wawancara, keterangan dari para narasumber menunjukkan fakta yang memberikan deskripsi dari peran komunitas pada kepuasan dan loyalitas pelanggan, yakni sebagai berikut.

"Jadi gini, perannya yang paling utama ialah pada saat komunitas mengadakan touring. Misalnya kalau HOG Jakarta bisa 50-100 motor sekali jalan ya, kemudianada orang lain lihat ada temen-teman lihat, yang belum mampu beli jadi pengen beli Harley dan yang sudah mampu pengen tukar tambah atau ganti motornya. Artinya apa? Secara gak langsung itu menjadi marketing tools seperti yang tadi anda bilang. Artinya apa? Artinya dealer sangat tergantung kepada komunitas. Kalau cuma memajang di showroomnya menjadi tidak menarik." (SM)

Narasumber SM memaparkan bahwa strategi yang digunakan HarleyDavidson terkait implementasi komunitas merek sangat efektif. Harley Owners Group (HOG) telah sukses dalam meningkatkan kepuasan dan loyalitas pelanggan Harley-Davidson. SM berujar bahwa kegiatan touring dari komunitas lah yang membuat menggunakan Harley-Davidson menjadi menyenangkan dan tentunya komunitas sangat berperan terhadap proses pembelian berulang yang disebabkan oleh aktivitas word of mouth yang dilakukan oleh anggota komunitas.

Begitu juga dengan pendapat WA dan BC yang berpendapat bahwa komunitas Harley-Davidson memiliki peran penting dalam aktivitas word of mouth merek Harley-Davidson dalam pernyataan beliau berikut ini.

"Ada beberapa teman seumuran saya yang memang dari muda penggila motor sport seperti kawasaki, ducati, dll. Namun seiring dengan bertambahnya usia, berkeluarga tentunya tidak akan cocok jika tarik gas terus seperti anak umur 21 tahun. Kemudian dia ganti motor dan Harley lah pilihannya. Kenapa Harley? Ya, karena dia lihat teman temannya sudah ada di komunitas Harley, ya ada kesamaan lah, umur relatif sama, perut sama-sama buncit, temen mainnya sama, obrolannya cocok, bisnisnya cocok, dan setelah masuk komunitas merasa fit dengan lifestyle kami sehingga akhirnya dia jadi loyal dengan Harley." (WA)

"Ya banyak. Itu ya karena hobby itu menular. Orang gak suka saya ceritain, saya ajak-ajakin. Saya suruh beli motor 1 dulu, tapi yang kayak gitu malah dia keranjingan, malah banyak beli motor, awalnya dia gak suka, terus jadi suka, feel nya dia dapat, malah beli lagi beli lagi. Saya sering ngajak teman buat beli lagi beli lagi." (BC)

WA dan BC dalam sesi wawancara memaparkan bahwa komunitas memiliki dampak signifikan dalam mempengaruhi penghobi motor untuk mencoba merasakan pengalaman berkendara bersama Harley-Davidson. Dalam banyak kasus, penghobi motor tersebut akhirnya merasa cocok dengan gaya hidup berkendara dan juga gaya hidup yang ditawarkan oleh komunitas Harley-Davidson dan akhirnya menjadi pengguna loyal Harley-Davidson. 
Fenomena loyalitas yang terjadi pada pelanggan Harley-Davidson telah mencapai tingkatan loyalitas tindakan. Pelanggan Harley-Davidson memiliki komitmen yang kuat untuk tetap menggunakan produk Harley-Davidson dan juga memiliki kesiapan bertindak dan keinginan untuk mengatasi hambatan untuk mencapai tindakan tersebut, berikut informasi yang disampaikan oleh narasumber berikut.

"Bisa cari sparepart paling deket di Australia. Ya paling lama 1 minggu sudah sampai barangnya. Motorpun banyak yang masuk dari sana, ya motor yang bodong. Nah itu mungkin akan mainl agi, karena dealer tutup akan jadi kesempatan buat mereka. Itu biasanya orang-orang di Jakarta, Bandung, Jogja, hebat-hebat mainnya. Ya kalau kita yang lokal daerah ya senang-senang saja kita gak ada urusan buat seperti itu.." (AA)

Narasumber AA menyampaikan bahwa jauh sebelum Mabua HarleyDavidson berdiri di Indonesia, komunitas Harley-Davidson sudah banyak berdiri. Pada masa itu, para pelanggan Harley-Davidson bahkan rela menanggung risiko dengan menyelundupkan sparepart untuk merakit Harley-Davidson di Indonesia.

Fenomena tersebut berlanjut ketika Mabua Harley-Davidson menyatakan berhenti menjadi dealer Harley-Davidson tidak menjadi halangan bagi pelanggan yang tergabung di Harley Owners Group (HOG) dan komunitas lainnya untuk tetap menjalankan hobi berkendara Harley-Davidson, seperti yang tertuang dalam pernyataan narasumber berikut ini.

"Kita, walau dealer itu masih buka atau tutup gak ada pengaruhnya, orang kita sudah hobi. Dia mau tutup ya tutup aja, cara lain masih banyak. Bengkel dealer tutup toh kita masih punya mekanik sendiri." (AA)

"Jadi begini, awalnya pasti ada dealer dia. Kemudian karena perubahan kondisi, HOG sudah jalan tapi dealer berhenti. HOG kan harus tetap eksis, harus tetap jalan tanpa dealer. Karena sekarang dealer sudah tidak ada, kita ini langsung diawasi oleh HDMC Singapore. Jadi sementara principalnya di Singapore.” (BC)

Narasumber AA dan BC menjelaskan bahwa keputusan Mabua HarleyDavidson untuk menutup lini usahanya tidak berpengaruh pada pelanggan HarleyDavidson. Pelanggan Harley-Davidson memiliki komimen dan loyalitas yang kuat terhadap merk Harley-Davidson dan selalu mencari cara untuk tetap bisa menjalankan hobi berkendara mereka.

\section{SIMPULAN}

Berdasarkan hasil penelitian yang dilakukan terhadap komunitas HarleyDavidson di Indonesia, dapat ditarik kesimpulan bahwa kelima Critical Success Factors (CSF) yang diteliti mendukung kesuksesan dari implementasi strategi komunitas merek Harley Davidson di Indonesia. Adapun kelima Critical Success Factors (CSF) tersebut yaitu ikatan dengan merek, faktor sosial, faktor fungsional, faktor hiburan, dan faktor ekonomi, beserta dua faktor pendukung yakni produk dan pelanggan. Untuk membentuk komunitas merek yang kuat, produsen harus mengerti kebutuhan anggota komunitas di lima CSF tersebut. Komunitas merek yang kuat akan berimplikasi bada peningkatan kepuasan dan loyalitas pelanggan, serta ekuitas merek. 
Selain kelima CSF tersebut, terdapat 2 faktor pendukung, yakni produk dan pelanggan. Dari sisi produk, implementasi dari komunitas merek akan efektif apabila ditunjang oleh produk yang diusung oleh komunitas tersebut memiliki diferensiasi yang kuat dibandingkan produk pesaing. Tentunya diferensiasi yang kuat harus didukung dengan kualitas produk serta citra premium yang dimiliki oleh merek tersebut. Dari sisi pelanggan., komunitas merek akan sangat efektif apabila digunakan pada produk yang keputusan pembeliannya dilakukan atas dasar pemenuhan kebutuhan ekspresif atau hedonis misalnya hobi,gaya hidup, gengsi dan perasaan subjektif lainnya. Efektivitas komunitas merek juga sangat berpengaruh pada kesesuaian antara nilai-nilai yang ditawarkan oleh merek dengan profil demografi dan psikografi dari target pasar.

Saran-saran yang dapat diberikan setelah melakukan penelitian mengenai Critical Success Factors (CSF) dalam pengelolaan komunitas merek HarleyDavidson di Indonesia, antara lain; (1) Implementasi dari kelima CSF tidak hanya pada komunitas Harley- Davidson resmi yang dibentuk oleh dealer melainkan juga kepada komunitas-komunitas hobi Harley-Davidson lain yang berdiri secara swadaya. Hal tersebut dapat diwujudkan dengan melakukan nota kesepahaman yang menguntungkan kedua belah pihak. Hal tersebut perlu dilakukan mengingat kuantitas dan peran serta komunitas hobi tersebut sangat besar terhadap ekuitas merek Harley-Davidson, (2) Adanya perwakilan dari pihak manajemen perusahaan yang menjabat dalam struktur kepengurusan dari tiap-tiap komunitas merek Harley -Davidson sebagai bentuk partisipasi aktif dan peningkatan kualitas komunikasi antara pihak dealer dan pelanggan, (3) Perlu dilakukan program-program khusus seperti gathering, touring, bakti sosial serta pemberian program diskon antara pihak dealer dengan komunitas-komunitas hobi, baik itu komunitas resmi dealer maupun komunitas hobi lain yang didirikan secara swadaya oleh pelanggan. Program ini ditujukan untuk menjalin hubungan yang lebih dekat dengan pelanggan dan menghilangkan dikotomi komunitas resmi dealer dan komunitas non-resmi (komunitas hobi) yang sepatutnya tidak saling bersaing namun saling melengkapi, (4) Bekerja sama dengan bengkel-bengkel Harley-Davidson non-dealerterutama dalam hal pelatihan teknis dan pengadaan suku cadang motor. Sehingga HarleyDavidson tidak hanya mampu memberikan kenyamanan kepada anggota komunitas di bengkel resmi dealer saja, melainkan juga di bengkel-bengkel mitra HarleyDavidson lainnya yang tersebar di berbagai lokasi. Bengkel non-dealer pun pada umumnya memiliki relasi yang erat dengan komunitas hobi Harley-Davidson, sehingga dengan adanya kerjasama tersebut diharapkan dapat meningkatkan peran dealer dalam memberikan informasi, edukasi teknis, dan pengalaman berkendara yang lebih optimal kepada pelanggan Harley-Davidson; (5) Pihak-pihak yang ingin mereplikasi strategi komunitas merek yang dilakukan Harley-Davidson hendaknya mampu mengkaji secara mendalam mengenai karakteristik produk dan target pasar yang diinginkan. Hal tersebut menjadi sangat penting dilakukan mengingat kedua faktor tersebut sangat menentukan efektifitas implementasi CSF terhadap kesuksesan komunitas merek yang dimiliki; (6) Penelitian selanjutnya diharapkan dapat membahas mengenai efektifitas implementasi CSF pada komunitas merekmerek non-premium atau produk-produk yang dikonsumsi atas dasar kebutuhan utilitarian. 


\section{REFERENSI}

Aaker, D. A. 1996. Managing Brand Equity. New York: The Free Press.

Algesheimer, René, Utpal M. Dholakia, and Andreas Herrmann. 2005. "The Social Influence of Brand Community: Evidence from European Car Clubs." Journal of Marketing 69(3):19-34.

Alsharari, Nizar Mohammad, and Mohammed Al-Shboul. 2019. "Evaluating Qualitative Research in Management Accounting Using the Criteria of 'Convincingness."' Pacific Accounting Review 31(1):43-62.

Babin, Barry J., William R. Darden, and Mitch Griffin. 1994. "Utilitarian Shopping Value.” Journal of Consumer Research 20(4):644-57.

Bronson, James W., and Graham Beaver. 2004. "Strategic Change in the Face of Success? Harley-Davidson, Inc.” Strategic Change 13(4):205-18.

Campbel, M. L., and F. M. Gregor. 2004. Mapping Social Relations: A Primer in Doing Institutional Ethnography. Walnut Creek, CA: AltaMira Press.

Carlson, Brad D., Tracy A. Suter, and Tom J. Brown. 2008. "Social versus Psychological Brand Community: The Role of Psychological Sense of Brand Community." Journal of Business Research 61(4):284-91.

Coulson-Thomas, C. 2004. A Business Classic, The Times Transforming The Company Manage Change, Compete and Win. Kogan Page.

Daniel. 1961. "Management Information Crisis." Harvard Business Review 39:110-19.

Dholakia, Utpal M., Richard P. Bagozzi, and Lisa Klein Pearo. 2004. “A Social Influence Model of Consumer Participation in Network- and Small-GroupBased Virtual Communities." International Journal of Research in Marketing 21(3):241-63.

Dholakia, Utpal M., Vera Blazevic, Caroline Wiertz, and René Algesheimer. 2009. "Communal Service Delivery." Journal of Service Research 12(2):208-26.

Fournier, Susan. 1998. "Consumers and Their Brands Developing." Journal of Consumer Research 24(4):343-53. 
Fournier, Susan. 2009. “Getting Brand Communities Right.” (April):105-12.

Garnefeld, Ina, Anja Iseke, and Alexander Krebs. 2012. "Explicit Incentives in Online Communities: Boon or Bane?” International Journal of Electronic Commerce 17(1):11-38.

Gummerus, Johanna, Veronica Liljander, Emil Weman, and Minna Pihlström. 2012. "Customer Engagement in a Facebook Brand Community." Management Research Review 35(9):857-77.

Hatch, J. A. 2002. Doing Qualitative Research in Education Settings. New York: Sunny Press.

Janita, Ike. 2009. Creating \& Sustaining Brand Equity. Jakarta: Amara Books.

Leidecker, Joel K., and Albert V. Bruno. 1984. "Identifying and Using Critical Success Factors.” Long Range Planning 17(1):23-32.

Mcalexander, James H., John W. Schouten, and Harold F. Koenig. 2002. "Marketplace Communities A Broader View of Brand Community." Journal of Marketing 66(January):38-54.

Milles, Mathew B., and M. A. Hubberman. 1992. Analisis Data Kualitatif: Buku Sumber Tentang Metode-Metode Baru. Jakarta: UI Press.

Moloeng, Lexy J. 2012. Metode Penelitian Kualitatif. Bandung: Remaja Rosdakarya.

Muniz, Albert M., and Thomas C. O'Guinn. 2001. "Brand Community." Journal of Consumer Research 27(4):412-32.

Nasution, S. 2003. Metode Penelitian Naturalistik Inkuiri. Bandung: Tarsito.

Rockart, John F. 1979. "Chief Executive Define Their Own Data Needs." Harvard Business Review 58:81-92.

Scapens, R. W. 2004. "Doing Case Study Research", in Humphrey, C. and Lee, B. (Eds), The Real Life Guide to Accounting Research: A behind-TheScenes View of Using Qualitative Research Methods. Oxford: Elsevier.

Schau, Hope Jensen, Albert M. Muñiz, and Eric J. Arnould. 2009. "How Brand Community Practices Create Value.” Journal of Marketing 73(5):30-51.

Sekaran, Uma, and Roger Bougie. 2013. Research Methods for Business. Sixth. edited by Wiley. United Kingdom. 
I Gede Nandya Oktora Panasea, Mengoptimalkan Komunitas Merek...

Stainback, Susan, and William Stainback. 1984. "Methodological Considerations in Qualitative Research." Journal of the Association for Persons with Severe Handicaps 9(4):296-303.

Stokburger-Sauer, Nicola. 2010. "Brand Community: Drivers and Outcomes." Psychology \& Marketing 27(4):347-68.

Sugiyono, M. P. A. 2005. Metode Penelitian Kuantitatif, Kualitatif Dan R\&D. Bandung: Alfabeta.

Tajfel, H. 1981. Human Group and Social Categories. Cambridge: Cambridge University Press.

Thompson, Scott A., Andrew M. Kalkati, and James M. Loveland. 2018. "Do Brand Communities Benefit Objectively Underperforming Products?" Journal of Business \& Industrial Marketing 33(4):457-65.

Wirtz, Jochen, Anouk Den Ambtman, Josée Bloemer, Csilla Horváth, B. Ramaseshan, Joris Van de Klundert, Zeynep Gurhan Canli, and Jay Kandampully. 2013. "Managing Brands and Customer Engagement in Online Brand Communities." Journal of Service Management 24(3):22344.

Woisetschlager, David M., Vivian Hartleb, and Markus Blut. 2008. "How to Make Brand Communities Work: Antecedents and Consequences of Consumer Participation.” Journal of Relationship Marketing 7(3):237-56. 